\title{
Fibrolipoma of the lip treated by diode laser surgery: A case report Saverio Capodiferro*1, Eugenio Maiorano ${ }^{2}$, Francesco Scarpelli ${ }^{3}$ and Gianfranco Favia ${ }^{1}$
}

\author{
Address: ${ }^{1}$ Department of Dentistry and Surgery, University of Bari, Piazza Giulio Cesare, 70124 Bari, Italy, ${ }^{2}$ Department of Pathological Anatomy, \\ University of Bari, Bari, Italy and ${ }^{3}$ University of Florence, Florence, Italy \\ Email: Saverio Capodiferro* - saveriocapodiferro@libero.it; Eugenio Maiorano - emaiorano@anatopat.uniba.it; \\ Francesco Scarpelli - scarpelli@aiola.it; Gianfranco Favia - g.favia@doc.uniba.it \\ * Corresponding author
}

Journal of Medical Case Reports 2008, 2:30I doi:10.1 I86/1752-1947-2-30I

This article is available from: http://www.jmedicalcasereports.com/content/2/1/30I

(C) 2008 Capodiferro et al; licensee BioMed Central Ltd.

This is an Open Access article distributed under the terms of the Creative Commons Attribution License (http://creativecommons.org/licenses/by/2.0), which permits unrestricted use, distribution, and reproduction in any medium, provided the original work is properly cited.

\begin{abstract}
Introduction: Several neoplasms of the adipose tissue can involve the soft tissues of the head and neck region. These neoplasms are mainly treated surgically and an accurate histological examination is mandatory for a precise diagnosis.

Case presentation: We report a case of fibrolipoma involving the lower lip of a 43-year-old man, which was successfully treated by diode laser surgery. This approach allowed adequate resection of the neoplasm with minimal damage to the adjacent tissues, thus reducing post-surgical scarring.

Conclusion: Diode laser surgery for the treatment of benign lesions of the oral mucosa appears to be a convenient alternative to conventional blade surgery and has proved to be effective for the excision of fibrolipoma of the lip. The possibility of avoiding direct suture after excision is surely helpful when aesthetic areas, such as the lip, are surgically treated. For these reasons, and also considering the lower histological alteration of the specimen obtained with diode laser surgery if adequately used, the diode laser is undoubtedly a good alternative to conventional surgery.
\end{abstract}

\section{Introduction}

Although the occurrence of conventional lipoma in the head and neck area is relatively high, fibrolipoma is quite rare within the oral cavity, particularly in the lip. This may result in equivocal differential diagnosis on clinical grounds and for this reason, subsequent histological examination is mandatory to confirm the nature of the tumour.

\section{Case presentation}

A 43-year-old man was referred to the Department of Dentistry and Surgery of the University of Bari for a painless swelling of the buccal mucosa of the lower lip of 8 months duration. At clinical examination, the lesion appeared soft and well separated from the surrounding tissues and was covered by intact mucosa (Fig. 1). No dental trauma was referred.

With a provisional clinical diagnosis of benign neoplasm, the lesion was surgically excised under local anaesthesia, using a diode laser with a $300 \mu \mathrm{m}$ fibre and operating at $2,5 \mathrm{~W}$. Direct suture of the surgical margins was unnecessary as no bleeding was observed during and following the excision (Fig. 2).

The surgical specimen was fixed in $10 \%$ buffered formalin, embedded in paraffin, cut and stained with haematoxylin-eosin. The histological preparations showed an 


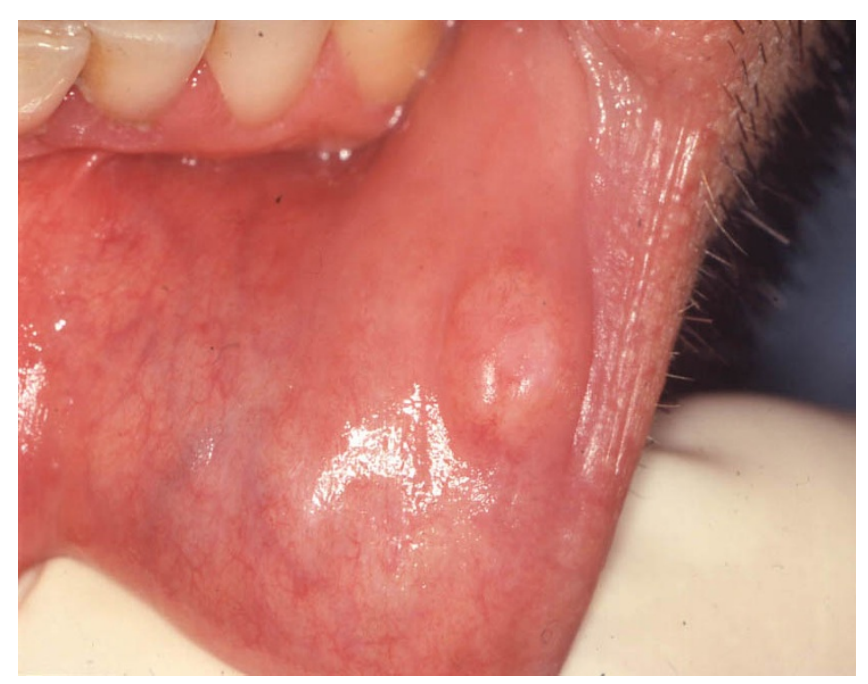

Figure I

Clinical appearance of fibrolipoma. This lesion usually presents as an asymptomatic swelling of soft consistency, mobile on the surrounding tissues.

admixture of mature adipose tissue, including variably sized typical adipocytes, embedded within dense collagen fibres (Fig. 3), consistent with fibrolipoma. Regressive changes of the tissues located at the surgical margins, such as cellular hyperbasophilia, nuclear chromatin condensations or tissue coarctation were not detected.

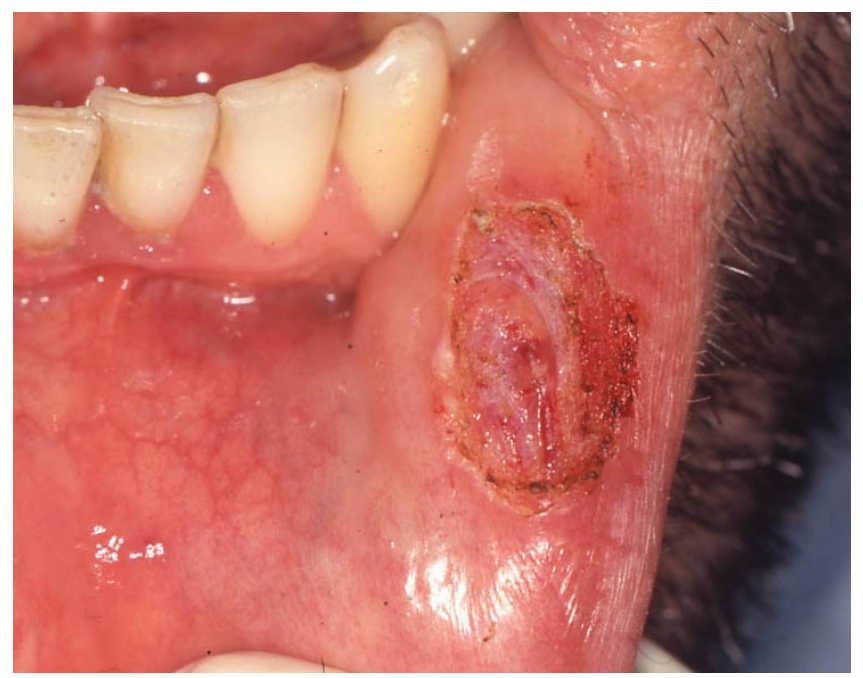

\section{Figure 2}

Clinical appearance of the surgical scar 10 days after surgery. The use of a diode laser with a $300 \mu \mathrm{m}$ fibre and operating at 2,5 W allowed prompt recovery of the patient, with no inaesthetic alterations of the adjacent tissues.

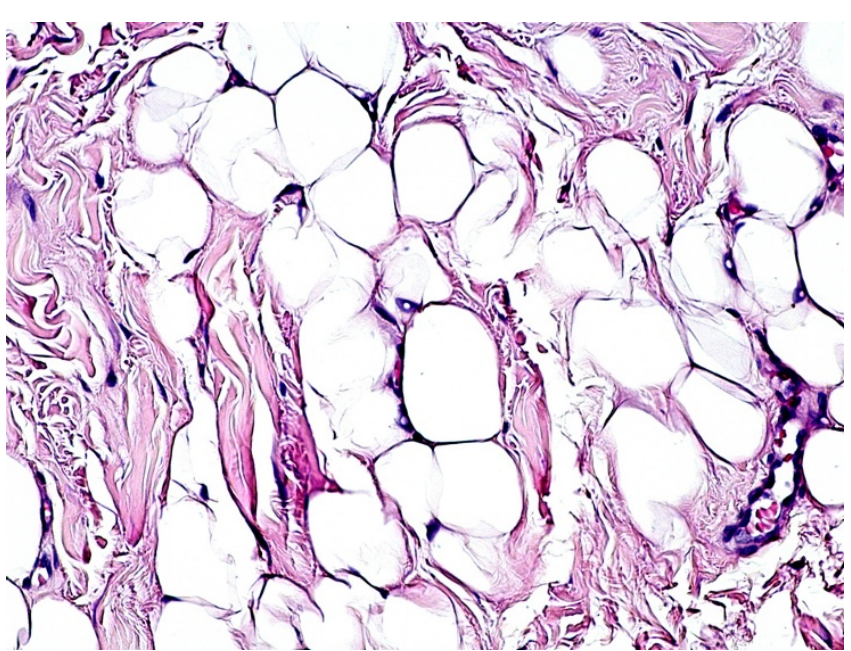

Figure 3

Histological features of fibrolipoma at high-power magnification. The tumour is composed of mature and univacuolated fat cells, embedded in dense collagen fibres. No morphological or structural alterations of the tissues due to the thermal cut of the diode laser are detectable (haematoxylin-eosin stain, original magnification $\times 20$ ).

The postoperative course was uneventful, with evident reduction of the surgical scar after 10 days and without signs of recurrence during a 10-month follow-up.

\section{Discussion}

Fibrolipoma is a benign tumour that rarely occurs in the oral and maxillofacial region, and is classified as a variant of conventional lipoma by the WHO [1]. Overall, lipomas represent $1 \%$ to $4.4 \%$ of all benign lesions of the oral cavity, and most frequently occur in the buccal mucosa, lip, tongue, palate and floor of the mouth [2-4]. Several variants of lipoma have been described, including angiolipoma, chondroid lipoma, myolipoma, spindle cell/ pleomorphic lipoma, diffuse lipomatous proliferations (lipomatosis) and hibernoma [1], some of which show distinctive clinico-pathological features that are usually discernible only after histological examination. Liposarcoma of the oral cavity is exceedingly rare [5], but this entity cannot be distinguished from its benign counterpart at clinical examination. Therefore, accurate histological examination is mandatory, and the differential diagnosis is based on the detection of a lack of lobular architecture, areas of prominent fibrosis and, most importantly, on the presence of multivacuolated adipose cells with indented nuclei (lipoblasts), which are typically present in liposarcoma in variable proportions.

The treatment of fibrolipoma is exclusively surgical but, to the best of the authors' knowledge, the use of diode laser surgery for oral fibrolipoma has not been reported previ- 
ously. In comparison with conventional blade surgery, laser excision seems more convenient in view of several intra-operative advantages (such as the lack of bleeding, no requirement for suture) and postoperative advantages (for example, faster scar healing, no inaesthetic sequelae). Furthermore, regressive tissue changes due to the thermal cut of the diode laser are usually negligible, as noted in the current study, thus allowing adequate histological examination and correct diagnosis.

\section{Conclusion}

Diode laser surgery for the treatment of benign lesions of the oral mucosa appears to be a convenient alternative to conventional blade surgery and has proved to be effective for the excision of fibrolipoma of the lip. In our patient, this surgical procedure allowed conservative treatment of the tumour, with no intra-operative haemorrhage, minimal tissue scarring, prompt recovery of the patient and without damage to the histological features of the lesion that might impair the correct diagnosis.

\section{Competing interests}

The authors declare that they have no competing interests.

\section{Consent}

Written informed consent was obtained from the patient for publication of this case report and any accompanying images. A copy of the written consent is available for review by the Editor-in-Chief of this journal.

\section{Authors' contributions}

SC, FS and GF carried out the surgical procedure with the diode laser while EM performed the histological examination. SF prepared the first draft of the manuscript while GF and EM undertook manuscript revision and editing. All authors read and approved the final manuscript.

\section{Acknowledgements}

The authors wish to thank KaVo for technical support and for supplying the GENTLEray 980 diode laser used for the surgical procedures.

\section{References}

I. Fletcher CDM, Unni KK, Mertens F: Adipocytic tumors. In Pathology and Genetics: Tumours of Soft Tissue and Bone. World Health Organization Classification of Tumours Lyon, France: IARC Press; 2002:9-46.

2. Fregnani ER, Pires FR, Falzoni R, Lopes MA, Vargas PA: Lipomas of the oral cavity: clinical findings, histological classification and proliferative activity of 46 cases. Int J Oral Maxillofac Surg 2003, 32:49-53.

3. Lombardi T, Odell EW: Spindle cell lipoma of the oral cavity: report of a case. J Oral Pathol Med 1994, 23:237-239.

4. Furlong MA, Fanburg-Smith JC, Childers EL: Lipoma of the oral and maxillofacial region: Site and subclassification of I 25 cases. Oral Surg Oral Med Oral Pathol Oral Radiol Endod 2004, 98:44I-450.

5. Capodiferro S, Scully C, Maiorano E, Lo Muzio L, Favia G: Liposarcoma circumscriptum (lipoma-like) of the tongue: report of a case. Oral Dis 2004, 10:398-400.

\footnotetext{
Publish with Biomed Central and every scientist can read your work free of charge

"BioMed Central will be the most significant development for disseminating the results of biomedical research in our lifetime. " Sir Paul Nurse, Cancer Research UK

Your research papers will be:

- available free of charge to the entire biomedical community

- peer reviewed and published immediately upon acceptance

- cited in PubMed and archived on PubMed Central

- yours - you keep the copyright

Submit your manuscript here:

http://www.biomedcentral.com/info/publishing_adv.asp 